\title{
Farmers' and Herders' Perceptions on Rangeland Management in Two Agroecological Zones of Benin
}

\author{
Rodrigue Vivien Cao Diogo ${ }^{1,2}$, Luc Hippolyte Dossa ${ }^{3,4, *}$, Sèyi Fridaïus Ulrich Vanvanhossou ${ }^{3}$ (D), \\ Badirou Dine Abdoulaye ${ }^{2}$, Kossi Hélliot Dosseh ${ }^{2}$, Marcel Houinato ${ }^{3}$, Eva Schlecht ${ }^{4}(D)$ and Andreas Buerkert ${ }^{1}$
}

1 Organic Plant Production and Agroecosystems Research in the Tropics and Subtropics (OPATS), University of Kassel, Steinstrasse 19, D-37213 Witzenhausen, Germany; rodrigue.diogo@fa-up.bj (R.V.C.D.); buerkert@uni-kassel.de (A.B.)

2 Laboratoire d'Innovation en Systèmes de Production IntégREs et de Gestion Durable des Terres (InSPIREs-GDT), Faculté d'Agronomie, Université de Parakou, BP 123 Parakou, Benin; abdoulayebadirou@gmail.com (B.D.A.); kossihelliot@yahoo.fr (K.H.D.)

3 Ecole des Sciences et Techniques de Production Animale, Faculté des Sciences Agronomiques, Université d'Abomey-Calavi, 03 BP 2819 Cotonou Jéricho, Benin; Seyi.F.Vanvanhossou-2@agrar.uni-giessen.de (S.F.U.V.); marcel.houinato@uac.bj (M.H.)

4 Animal Husbandry in the Tropics and Subtropics, Universität Kassel and Georg-August-Universität Göttingen, Steinstrasse 19, D-37213 Witzenhausen, Germany; schlecht@uni-kassel.de

* Correspondence: hippolyte.dossa@fsa.uac.bj

check for updates

Citation: Diogo, R.V.C.; Dossa, L.H.; Vanvanhossou, S.F.U.; Abdoulaye, B.D.; Dosseh, K.H.; Houinato, M.; Schlecht, E.; Buerkert, A. Farmers' and Herders' Perceptions on Rangeland Management in Two Agroecological Zones of Benin. Land 2021, 10, 425. https://doi.org/ 10.3390/land 10040425

Academic Editor: Didier Genin

Received: 16 February 2021

Accepted: 11 April 2021

Published: 16 April 2021

Publisher's Note: MDPI stays neutral with regard to jurisdictional claims in published maps and institutional affiliations.

Copyright: (c) 2021 by the authors. Licensee MDPI, Basel, Switzerland. This article is an open access article distributed under the terms and conditions of the Creative Commons Attribution (CC BY) license (https:// creativecommons.org/licenses/by/ $4.0 /)$.
Abstract: The sustainable use of rangelands in pastoral areas requires the inclusion of all stakeholders to develop sound management strategies. However, the role of these actors in the sustainable management of natural resources is still poorly understood. The present study aims to (i) assess the perception of farmers and herders of the risks and opportunities of transhumance on rangeland resource use and management, and to (ii) generate useful knowledge for the design and implementation of policies that favor the coexistence of these actors and reduce competition over rangeland resources use in Benin. To this end, interviews were conducted with 240 crop farmers and herders using a semi-structured questionnaire in two contrasting agroecological zones in the northern (Kandi) and the southern (Kétou) part of the country. Among the respondents, $64 \%$ of farmers in the North were agro-pastoralists (owning 10.6 ha of land and 10.7 cattle) and 36\% were herders (keeping 45.8 cattle and cultivating about 3.7 ha of land). They perceived that communal rangelands were entirely degraded. In the South, $36 \%$ of respondents were agro-pastoralists (with 0.3 cattle and farming 4 ha of land) and $64 \%$ cattle herders (raising 45.3 cattle and farming 0.9 ha of land only). Of the herders, 50\% kept cattle for more than 20 years, while agro-pastoralists had no previous experience in cattle herding. Cultivation practices among crop farmers, such as high use of mineral fertilization (23.8\%) and bush fires for land clearing (22.5\%), were reported in Kandi (North) and Kétou (South) as factors that might contribute to land degradation. However, these farmers perceived transhumance as a threat to the sustainable use of natural resources. In contrast, herders perceived transhumance as an opportunity to valorize unused land and increase the availability of manure to cropland. The prevalent negative attitude of crop farmers regarding transhumant herders increases the vulnerability of cattle herding in both regions. There is an urgent need of raising awareness concerning the mutual benefits provided by the coexistence of crop farmers with herders to promote participative rangeland management strategies. This may contribute towards coping with the current challenges of food insecurity and increasing climate variability as well as to reducing recurrent conflicts in the region.

Keywords: communal grazing areas; herder-farmer conflicts; herd mobility; land property rights; rangeland degradation; West Africa 


\section{Introduction}

In Africa, pastoralists have provided meat and milk to rural populations for millennia, using seasonal and cyclical migration to cope with changing fodder availability over time and space [1-4], a phenomenon known as transhumance. This livelihood strategy substantially contributes to food security and the economies of many communities [2] in seasonal climates with resulting drylands across the continent. Transhumance is viewed as an economically and ecologically rational production system, essential for livestock in areas exposed to high annual variability in rainfall or temperature $[3,5]$. Unfortunately, this rangeland-based lifestyle is increasingly threatened by competing claims for land by crop farmers, sedentary herders, and other community actors [6,7].

In Benin, cattle herding is mainly based on animal mobility during the dry seasons. This production system contributes $75 \%$ to the national cattle production [8,9]. Moreover, every year, Benin receives more than 2 million cattle from Nigeria and the Sahelian countries of Niger, Burkina Faso, and Mali [10]. In the past, the general trend of transhumance practices in West Africa has been placed on increasing livestock movement into SudanoSahelian and Sudano-Guinean zones [11,12]. These increased movements by transhumant herders have resulted in growing competition for natural resources [13]. Moreover, due to demographic pressure, encroachment of cultivated fields into grazing areas and livestock corridors has increased [4] and constrains the mobility of animals. National and regional policies including laws that regulate the practice of pastoralism and the management of common rangeland resources in Benin and in West Africa exist but are poorly enforced [9]. Umutoni and Ayantunde (2018) [13] argued that the existing local institutions are sometimes slow in addressing the dynamics of natural resource use in response to demographic pressure and new economic interest. As reported by Umutoni et al. (2016) [14] in the case of southern Mali, natural resource governance is weak, as the majority of regulations/laws are oral, and the participation of the community members in their elaboration is very low. To prevent recurrent cycles of violent conflicts between transhumant herders and farmers, the parliament of Benin revised the national pastoral code in July 2018, which ignores the interests of various community actors and their perceived effects of transhumance on natural resource conservation. The new regulation came into force in April 2019, and restricts transhumance in the country. Umutoni and Ayantunde (2018) [13] advocate for the reinforcement of local institutions that regulate access to natural resources and use by various actors. The same authors reported increased unauthorized grazing of crop residues in Bougouni (southern Mali) and a decline in the availability of forage resources and annual production of vegetation. Moreover, farmers and settled transhumant herders provided similar reports on declining soil fertility and palatable forage species [13]. While livestock herding remains the most important income activity for households in pastoral settlements [15], there is an urgent need to reduce conflicts between herders and crop farmers in order to sustain cattle production and ensure food security for the local communities. This, however, requires a better understanding of the driving forces of resource degradation and its mitigation [16].

Both local communities and transhumant herders exploit rangelands as common-pool resources $[17,18]$. Therefore, investigating how various stakeholders use these natural resources and interact with one another is crucial for designing appropriate strategies for the sustainable management of agro-pastoral land use systems. Thereby, existing studies on the effects of transhumance on host communities and the natural environments have to be taken into account $[19,20]$.

In sub-Saharan Africa, the relationships between pastoralists, their livestock, and environments are complex and have been fraught with controversy [20]. Pastoralists and their animals have been described as responsible for "overgrazing" and "degradation" of the environment through "overstocking" and "poor management techniques" [21,22], which may affect the productivity and sustainable use of rangeland resources. The most significant effects reported in the Sudano-Sahelian and Sudano-Guinean zones include increased unrestricted grazing, incidence of uncontrolled bush fires, and abusive cutting of 
trees by the pastoralists as well as overgrazing [23,24]. Previous investigations on pasture management by transhumant herders in two host areas in Benin [25] partly confirmed this trend and identified poor distribution of livestock on pasture as one of the main causes for overgrazing. This was associated with the intrusion of invasive plant species, which means that land degradation must be more pronounced in areas with strong rather than weak transhumance. However, the ecological processes leading to rangelands' degradation are complex and cattle herding cannot be its only cause. Similarly, climatic variations, climate change, changes in agricultural practices, population pressure, and other societal changes may substantially contribute to modifications in the agroecosystem $[3,26,27]$. Therefore, adaptation to a changing landscape for adjusting the needs of livestock and improving meat and milk productivity may become an increasing challenge for food security, the resilience of rangelands, and the sustainability of their utilization. In this context, Steinfeld et al. (2013) [28] argued that the change of practices in extensive livestock production modifies pressures on resources and ecosystems. Rangelands provide essential forage for animals and a habitat for wildlife in many places worldwide [29]. Many human communities, including pastoralists, directly depend upon rangelands for their livelihoods [30]. It is estimated that rangelands store $10-30 \%$ of the world's soil carbon, in addition to the substantial amount of above-ground carbon in trees, bushes, shrubs, and grasses [31]. As ecosystems become degraded, their capacity to deliver such services is undermined [32]. The degradation of biophysical rangeland resources has serious implications for pastoral ecosystems, livelihoods, and livestock production [33].

In Benin, the majority of studies on rangeland management were conducted in the northern part of the country while little attention was paid to pastoral resource use and management in the South. Moreover, these studies mostly focused on resource management and conflicts around protected areas [34-38]. So far, no study was conducted on the risks and opportunities of transhumance as perceived by various community actors. Additionally, the effect of resource availability in agroecosystems on resource use and user perceptions remains unstudied. Therefore, this study aimed at assessing the perception of farmers and herders on rangeland resource management, so as to advise decision makers in implementing appropriate policies that favor the coexistence of these actors. To this end, we hypothesized that the perceptions of rangeland degradation by different users depend on their socio-economic conditions and their use of the rangeland.

\section{Theoretical Background Underpinning Social, Economic and Ecological Practice of Transhumance and Resource Use and Management in West Africa}

Demographic, socio-economic, political, technological, cultural, and/or biophysical factors are hindering the availability of and the accessibility to pastoral resources in many parts of Africa [39]. These resources include land, pasture, crop residues, livestock corridors, and water points like dams, wells, boreholes, and streams. Due to population pressure, rising demand for food, and changes in food habits of an increasingly urbanized population, the global meat production has substantially increased during the past three decades and has been predicted to double by 2030 [28]. In West Africa, this has also enhanced the importance of livestock husbandry as a source of food, income and employment, savings, and as an insurance system $[40,41]$. In sub-Saharan Africa, about 25 million pastoralists and 240 million agro-pastoralists rely on livestock grazing in drylands for their livelihoods [31]. In this context, mobility enables pastoralists to opportunistically use the scarce pasture resources, including forage and water [42], and thus optimize weight gain and milk production of their herds [43]; it also gives them better access to markets. Among all factors bringing about transhumant pastoralism, the ecological context seems to be the most likely to cause conflicts since scarcity of land and water competition have been recognized as major causes of farmer-herder conflicts [44]. Long dry season periods in Sahelian countries induce water and fodder scarcity and, in consequence, animal diseases $[4,10]$; they therefore remain important reasons for transhumance [34,45]. Climate change effects may enhance causes for transhumance wherever dry seasons become longer and drier, increasing the competition for natural resources [45]. The competition for land has become an issue 
of major concern $[46,47]$. Decreasing nutritional quality of herbaceous plants during the dry season may induce herders to abusive cutting of fodder trees to feed their livestock without the agreement of local farmers [45]. This was also recently reported from southern Benin where animals' diets shifted to higher protein levels as they contained up to $70 \%$ Fabaceae [48].

Despite the vital contribution of pastoral systems to food security and their ability to produce and thrive in regions unfavorable to agriculture [46], pastoralism and pastoralists' lifestyles are under increasing threat around the world [38,49]. Farmer-herder conflicts contribute a lot to this situation, as a consequence of the encroachment of arable farming into pastoral ecosystems, leading to a loss or fragmentation of pastoral lands, obstruction of water points, and shrinking of livestock corridors [39]. In Benin, a recent study reported crop expansion around the $\mathrm{W}$ Biosphere Reserve; population growth, raising demand for food crops, and government support to the cotton sector were direct causes for shrinking grazing land [38]. For a long time, governments and international development agencies have neglected the needs of pastoral populations and confronted them with poorly designed interventions [46]. Furthermore, a marked intensification and shift towards more sedentary livestock production systems of mobile herders was observed [50]. Therefore, understanding drivers of rangeland degradation and views of various actors is a prerequisite for designing better policies for the coexistence of different stakeholders and a more sustainable use and management of rangeland resources. According to a recent study [4], indigenous farmers tend to portray the transhumance practices as generally bad for community-based natural resource management and degradation.

Correspondingly, the socio-cultural context may fuel conflicts because pastoral movements influence social relations between stakeholders [5]. The existence of conflicts or, alternatively, privileged links between domestic, cross-border transhumant herders, and local farmers may allow or prohibit access to a water point or some grazing areas [18]. Van Driel (2001) [51] claimed that enhanced competition for resources causes a rise in ethnic and religious antagonisms. Crop farming and pastoralism were linked to the identities of, respectively, local communities and pastoralists (Fulani); therefore, any change of these identities may raise conflicts [35]. Often, new socio-political realities determine such identity changes. To adapt to environmental and institutional changes, farmers and herders have at many locations resorted to the same activities [36]. Farmers in northern Benin have increasingly integrated livestock farming into their activities to diversify and increase agricultural production and to supplement their income, while pastoralists have integrated cropping into their pastoral activities to become more independent from crop farmers $[52,53]$.

\section{Study Area}

The study was conducted in two contrasting eco-regions of Benin: Kandi (in the northeast) and Kétou (in the southeast) that are both strongly influenced by cattle keeping and transhumance (Figure 1).

Kandi belongs to the administrative subdivision of Alibori. It is one of the country's northern regions, which receives foreign transhumant herds from Niger through the town of Angaradebou, the main cattle gathering point in Benin. It is located in the agro-pastoral zone where about $80 \%$ of the national cattle population is kept [8]. With a unimodal rainfall pattern and a dry tropical climate in a Sudanese region, the natural vegetation in Kandi is dominated by woody and shrubby savannas and clear forests. Many protected forests offer pasture zones for local and foreign herds. Despite the importance of livestock production, cattle keeping coupled with cotton (Gossypium hirsutum L.), maize (Zea mays L.), and sorghum (Sorghum bicolor Moench) production are the main sources of income for the local farmers [54]. 

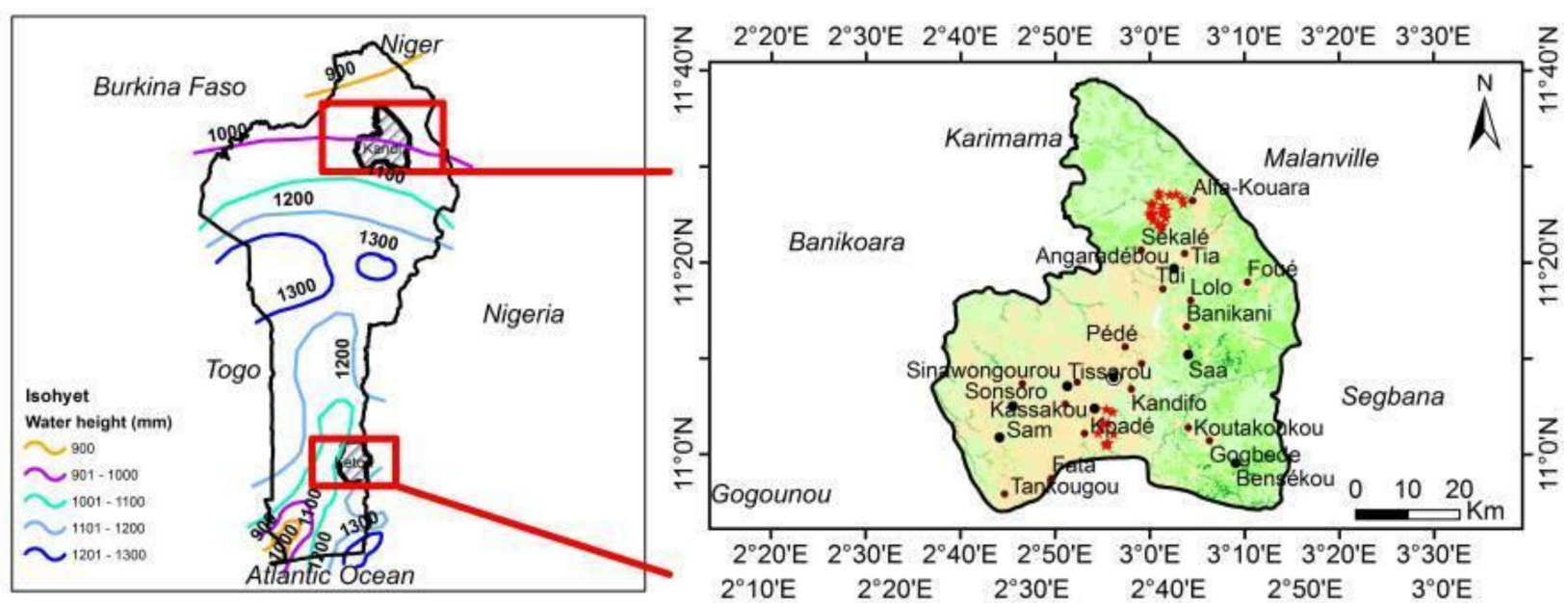

- Main town of municipality

- Main town of municipality subdivision

- Village, quarter, hamlet

* Study locations

Dense forest

= Gallery forest

- Clear forest and woodland savannahs Woody and shrubland savannahs

::::Plantation

Crop fied mosaic and fallow

Crop fied mosaic and fallow under palm

Source:IFN 2007 \& Field data

Projection system: WGS 84 UTM 31 Zone N

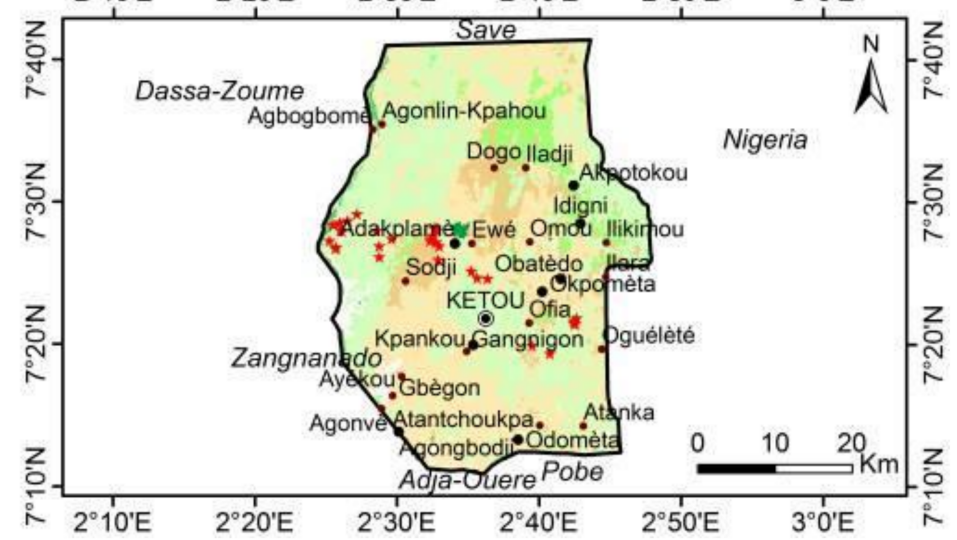

Figure 1. Map of Benin showing the locations of the study areas: Kandi in northeastern and Kétou in southeastern Benin (left) and the land use types in Kandi (top right) and Kétou (bottom right).

Kétou is the second municipality studied. It is considered as the main host area for transhumant cattle in the Guinean zone of Benin [8]. Its climate is tropical and characterized by a bimodal rainfall pattern. Due to its protected forests, woody savannas, and some permanent and seasonal waterways, this area provides several feeding opportunities for local, regional and foreign transhumant herds. Livestock production is the most important local livelihood strategy complemented by cultivation of rainfed maize, yam (Dioscorea spp.), cassava (Manihot esculenta Crantz), cowpea (Vigna unguiculata Walp.), and peanut (Arachis hypogaea L.) [55].

\section{Methods}

As no list of primary natural resource users was available, the respondents/farmers' groups were selected using a snowball sampling approach. The initial respondents were identified through a focus group discussion with the chief of the village who gathered them in each study site ( 5 per group). They were informed about the purpose of the study and assured that any information would only be used for research anonymously. After obtaining the participants' consent, an appointment was made and a semi-structured questionnaire was administered according to the status of the respondents as defined by their use of communal rangelands and whether they herded cattle (herders) or grew crops (farmers). Each of them referred to his neighbor until the maximum representation is reached. A total of 240 crop farmers and pastoralists were sampled in Kandi $(n=120)$ and Kétou $(n=120)$. Regardless of the status of the respondents, data were collected on the size of cultivated land and/or cattle owned, the practices of herding and pasture management, and perception of transhumance and its impacts on local resources. Herders were additionally asked for their perception of the quality of pastures, the main types of 
feeds grazed by their cattle and their palatability. For qualitative data, binary and multiple choice questions were asked and the respondent selected freely one answer without any interference from the surveyor. The frequencies of responses were presented per category.

Subsequently, the sampled respondents were categorized according to their crop and livestock management strategies, whereby sole livestock herders and crop farmers were separated from the other actors. Pure herders were those who owned cattle but did not cultivate land, whereas pure crop farmers cultivated land but owned no cattle. Subsequently, we applied a two-step clustering algorithm to classify the remaining actors following the clustering approach described by Dossa et al. (2015) [56]. Considering the correlation between the variables and their importance in the model, only the size of cropped fields and cattle herds were finally retained as they explained more than $60 \%$ of the difference between the respondents (overall silhouette measure of cohesion and separation) and accounted for $100 \%$ and $93 \%$ of the final classification, respectively. Four sub-groups resulted from this classification, and two of them, including respondents with high cultivated land area (ha) and few cattle, were considered to form, together with the pure crop farmers, the group of the "agro-pastoralists". The two remaining sub-groups (including respondents with large cattle herds and small area of cultivated land) formed the group of "herders" together with the pure herders Supplementary file 1). The agropastoralists and the herders were further compared between the two regions studied.

Descriptive analysis allowed to condense the information gathered and explore statistical differences between groups. Arithmetic means and median (in parentheses) were calculated for quantitative data.

The responses' percentages for qualitative data on the rangeland use and management and on the perceptions of different actors of the effects of transhumance on resource use and crop yield were presented per group.

Furthermore, a comparison of the management practices of rangeland between the two locations was generated for each actor, and chi-square $\left(\chi^{2}\right)$ plus Bonferroni tests were used to compare the percent responses between sites (refer to Supplementary Materials). All statistics were computed using the Statistical Package for Social Sciences (SPSS) version 24 [57].

\section{Results}

\subsection{Rangeland Management of Respondents}

The resources owned by respondents and their main economic activity influence rangeland resource use and management. We observed an unequal distribution of the actor categories between the regions, as the majority of respondents in Kétou were herders, whereas those located in Kandi were mainly agro-pastoralists (Figure 2). The agro-pastoralists farmed an average of 8.3 ha and owned 7 cattle while the cattle herders kept 46 cattle and cultivated 1.9 ha of land. The agro-pastoralists in Kandi cultivated larger croplands than those in Kétou, but comparable cattle herds were kept by the herders at the two locations (Table 1). Fifty percent of the herders kept cattle for more than 20 years while $67 \%$ of the agro-pastoralists had no previous experience in cattle herding. Lack of experience in cattle herding was more frequently reported in Kétou than in Kandi. 


\section{- Agro-pastoralists $\quad$ Herders}

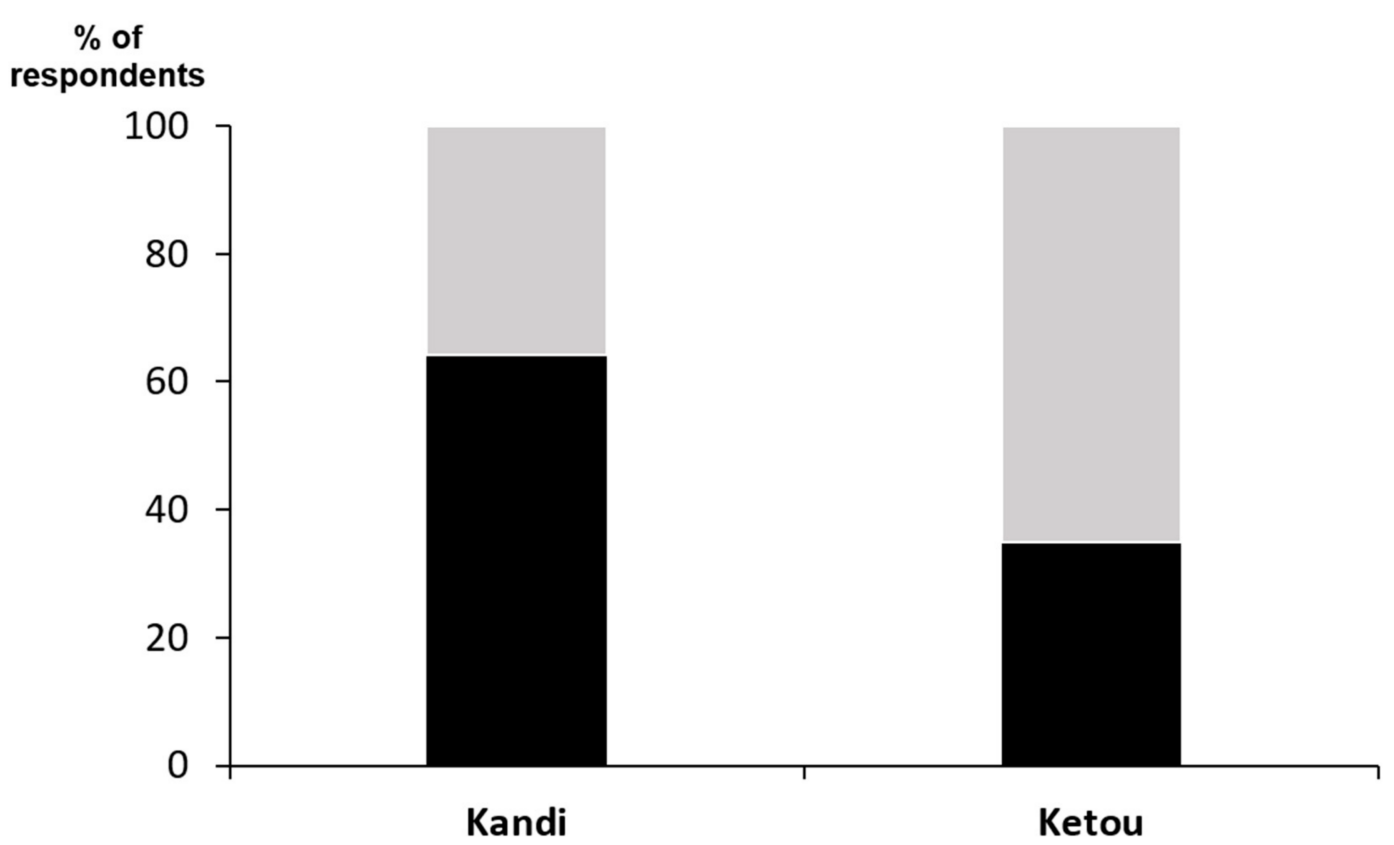

Figure 2. Simplified representation of the clusters obtained in northeastern (Kandi) and southeastern (Kétou) Benin.

Table 1. Groups of farmers surveyed in the municipalities of Kandi (northeastern Benin, $n=120$ ) and Kétou (southeastern Benin, $n=120$ ).

\begin{tabular}{|c|c|c|c|c|}
\hline \multirow{2}{*}{ Variable } & \multicolumn{2}{|c|}{ Kandi $(n=120)$} & \multicolumn{2}{|c|}{ Kétou $(n=120)$} \\
\hline & Agro-Pastoralists & Herders & Agro-Pastoralists & Herders \\
\hline & $(n=77)$ & $(n=43)$ & $(n=42)$ & $(n=78)$ \\
\hline Herd size $(n)$ & $10.65(6) *$ & $\begin{array}{c}45.81 \\
(45)\end{array}$ & $0.33(0)$ & $45.28(30)$ \\
\hline $\begin{array}{l}\text { Cultivated land size (ha) } \\
\text { Experience in cattle } \\
\text { herding }(\%)\end{array}$ & $10.64(9)$ & $3.70(3)$ & $4.04(4)$ & $0.92(1)$ \\
\hline 0 & 51.9 & 0 & 95.2 & 0 \\
\hline$>0, \leq 10$ years & 13.0 & 25.6 & 0 & 7.7 \\
\hline$>10, \leq 20$ years & 20.8 & 34.9 & 2.4 & 37.2 \\
\hline$>20, \leq 50$ years & 14.3 & 39.5 & 2.4 & 55.1 \\
\hline
\end{tabular}

* Values in bracket represent the medians.

Most of the investigated herders grazed their cattle on a mosaic of natural pastures and harvested crop fields. In Kétou, $99 \%$ of the herders used mainly rangelands like forests and savannas, whereas $62.8 \%$ of the Kandi herders used fallow and/or harvested cropland $(p<0.05)$. About $55 \%$ of the herders in the two locations used the same grazing areas each year. Herders from Kandi practiced only permanent grazing (58\%, using the same rangeland continuously) or rotational grazing (30\%, changing and re-using initial grazing sites), while all herders from Kétou practiced mixed grazing compared to Kandi $(p<0.05$, Table S2). According to $96 \%$ of the herders in Kétou, the vegetation on the current pasture areas was less dense than five years ago, whereas $65 \%$ of the herders in Kandi responded that rangelands are degraded today compared to five years ago $(p<0.05$, Table S2). This degradation of grazing areas affected $95 \%$ and $53 \%$ of the herds in Kandi and Kétou, respectively, with perceived severe consequences such as consumption of low-quality grasses $(43 \%)$ and low feed intake $(20 \%)$. Herders in Kétou mainly provided 
feed supplements to their cattle (94\%), while transhumance was practiced as a remediation strategy by $35 \%$ of herders in Kandi compared with $6 \%$ in Kétou $(p<0.05$, Table S2).

According to $58 \%$ of the herders interviewed (33\% in Kandi and $83 \%$ in Kétou), grazing areas were dominated by Poaceae. Cyperaceae were noticed to be dominant by $14 \%$ of the herders in Kétou, while $54 \%$ of those in Kandi answered that there were no dominant grasses on the pastures. All herders from Kandi and 97\% of those from Kétou reported that Poaceae were the most preferred plants grazed by cattle. Cyperaceae and tree leaves were also moderately preferred according to $58 \%$ of the respondents.

Considering the agro-pastoralists, $97 \%$ of the respondents from Kandi and $45 \%$ from Kétou reported that their fields were no more productive (Table S3, $p<0.05$ ). There were significant differences $(p<0.05)$ in farming practices between the two municipalities. About $52 \%$ of the farmers from Kandi used mineral fertilizers and crop rotation compared to $38 \%$ using mineral fertilizers and $45 \%$ practicing crop rotation in Kétou. The application of manure to crop fields by cattle herders (through corralling) was barely practiced (4\% of respondents) and only seen in Kandi. The use of fallow for soil fertility restoration was reported by $21 \%$ of the farmers in Kétou compared with $6 \%$ in Kandi, whereas controlled use of bush fire for land clearing was commonly practiced by $69 \%$ of farmers in Kétou compared with $22 \%$ in Kandi. As stated by $51 \%$ of the respondents, these management practices were used to improve the fertility of their land or to protect their farms against fire set by their neighbors ( $26 \%$ of respondents, Table S3).

\subsection{Perceptions on Rangeland Management}

Respondents reported that rangelands (uncultivated lands including fallow lands used for grazing) were differently used (Table 2). Overall, $45 \%$ of the respondents $(66 \%$ of the agro-pastoralists against $25 \%$ of the herders) did not use their uncultivated lands but left them fallow. However, in Kétou, fallows were used by all herders for grazing and cattle corralling. According to $82 \%$ of the interviewed agro-pastoralists and $55 \%$ of the herders, overgrazing was the main cause of rangeland degradation. These observations were reported by both categories of respondents in Kandi, whereas most of the cattle herders in Kétou identified bush fires as the main reason for rangeland degradation. Agropastoralists, almost unanimously (95\%), stated that there were no specific areas allocated to cattle grazing and long-distance mobility (trekking corridors), while herders had different views on this. In contrast to Kandi, the majority of the herders acknowledged the existence of specific pasture areas and corridors in Kétou. Independent of their categories, conflicts between farmers and herders were reported by $68 \%$ of all respondents, whereby the main cause of such conflicts was crop destruction ( $53 \%$ of the total sample). The latter viewpoint was largely expressed by the agro-pastoralists in Kétou. In Kandi, the herders reported diverse causes of conflicts, including livestock corridors' occupation by crop farmers, intrusive cattle killed by land owners, and even murder of herders (Table 2).

\subsection{Perceived Effects of Transhumance}

Transhumance reportedly creates some opportunities (Table 3). In general, $63 \%$ of the cattle herders against $22 \%$ of the agro-pastoralists perceived cattle mobility as an opportunity to valorize land not used for crop farming. In contrast to the view of herders, cattle mobility did not favour soil and vegetation for the majority of the agro-pastoralists in Kétou. However, the perceptions were diverse and comparable within the two groups in Kandi. According to the majority of the herders and some agro-pastoralists, transhumance promotes the substitution of mineral fertilizer by organic amendments ( $24 \%$ of total respondents in the sample) and increases the local demand for manure and cattle corralling ( $18 \%$ of total respondents in Kandi). Similarly, $41 \%$ of the total respondents ( $52 \%$ in Kandi against $30 \%$ in Kétou) reported that crop yield increased on land corralled by transhumant herds. The positive impacts of transhumance on crop production was supported by the agro-pastoralists in Kandi but was, in the majority, contradicted by those located in Kétou. The latter reported that rangelands were more eroded and less productive after the 
passage of transhumant herds. In addition, the agro-pastoralists in Kétou reported that transhumance introduced invasive plant species $(71 \%)$, whereas it caused disappearance of valuable grass species according to the majority of the agro-pastoralists in Kandi. On the contrary, the herders of the two regions defended that transhumance induces no changes in the quality and quantity of feed resources (Table 3).

Table 2. Rangeland use and management by agro-pastoralists and cattle herders from Kandi $(n=120)$ and Kétou $(n=120)$ in Benin. Values depict percent of responses per group.

\begin{tabular}{|c|c|c|c|c|}
\hline \multirow{2}{*}{ Variable } & \multicolumn{2}{|c|}{ Kandi $(n=120)$} & \multicolumn{2}{|c|}{ Kétou $(n=120)$} \\
\hline & Agro-Pastoralists & Herders & Agro-Pastoralists & Herders \\
\hline & $(n=77)$ & $(n=43)$ & $(n=42)$ & $(n=78)$ \\
\hline \multicolumn{5}{|l|}{$\begin{array}{c}\text { Use of non-cultivated } \\
\text { land }\end{array}$} \\
\hline Cattle grazing & 13.0 & 16.3 & 0 & 0 \\
\hline Fallow + cattle grazing & 18.2 & 7.0 & 4.8 & 0 \\
\hline Fallow & 9.1 & 2.3 & 9.5 & 0 \\
\hline $\begin{array}{l}\text { Cattle grazing + cattle } \\
\text { corraling }\end{array}$ & 0 & 4.7 & 7.1 & 100.0 \\
\hline Nothing & 59.7 & 69.8 & 78.6 & 0 \\
\hline \multicolumn{5}{|l|}{$\begin{array}{l}\text { Practices causing } \\
\text { rangeland degradation }\end{array}$} \\
\hline Overgrazing & 80.5 & 79.1 & 83.3 & 42.3 \\
\hline Bush fires & 9.1 & 11.6 & 16.7 & 44.9 \\
\hline $\begin{array}{l}\text { Pasturing in cropping } \\
\text { areas }\end{array}$ & 10.4 & 9.3 & 0 & 12.8 \\
\hline \multicolumn{5}{|l|}{$\begin{array}{l}\text { Existence of specific } \\
\text { pasture areas/corridors }\end{array}$} \\
\hline Yes & 6.5 & 27.9 & 2.4 & 57.7 \\
\hline No & 93.5 & 72.1 & 97.6 & 42.3 \\
\hline \multicolumn{5}{|l|}{ Existence of conflicts } \\
\hline Yes & 55.8 & 67.4 & 88.1 & 67.9 \\
\hline No & 44.2 & 32.6 & 11.9 & 32.1 \\
\hline \multicolumn{5}{|l|}{ Cause of conflicts } \\
\hline Crop damage & 42.9 & 20.9 & 97.6 & 56.4 \\
\hline $\begin{array}{l}\text { Blockage of pastoral } \\
\text { infrastructures }\end{array}$ & 15.6 & 25.6 & 2.4 & 10.3 \\
\hline $\begin{array}{l}\text { Cattle slaughter or } \\
\text { murder of herders }\end{array}$ & 1.3 & 20.9 & 0 & 3.8 \\
\hline Nothing & 40.3 & 32.6 & 0 & 29.5 \\
\hline
\end{tabular}

Table 3. Perceptions of different actors of the effects of transhumance on resource use and crop yield in Kandi $(n=120)$ and Kétou $(n=120)$ in Benin. Values depict percent of responses per group.

\begin{tabular}{|c|c|c|c|c|}
\hline \multirow{2}{*}{ Variable } & \multicolumn{2}{|c|}{ Kandi $(n=120)$} & \multicolumn{2}{|c|}{ Kétou $(n=120)$} \\
\hline & Agro-Pastoralists & Herders & Agro-Pastoralists & Herders \\
\hline & $(n=77)$ & $(n=43)$ & $(n=42)$ & $(n=78)$ \\
\hline $\begin{array}{c}\text { Benefits of herd } \\
\text { mobility for soil and } \\
\text { vegetation }\end{array}$ & & & & \\
\hline $\begin{array}{l}\text { Valorization of land } \\
\text { unused for crop } \\
\text { farming }\end{array}$ & 23.4 & 20.9 & 19.0 & 85.9 \\
\hline $\begin{array}{l}\text { Soil protection against } \\
\text { erosion }\end{array}$ & 27.3 & 30.2 & 0 & 12.8 \\
\hline Soil compaction & 18.2 & 20.9 & 4.8 & 0 \\
\hline Nothing & 31.2 & 27.9 & 76.2 & 1.3 \\
\hline
\end{tabular}


Table 3. Cont.

\begin{tabular}{|c|c|c|c|c|}
\hline \multirow{2}{*}{ Variable } & \multicolumn{2}{|c|}{ Kandi $(n=120)$} & \multicolumn{2}{|c|}{ Kétou $(n=120)$} \\
\hline & Agro-Pastoralists & Herders & Agro-Pastoralists & Herders \\
\hline & $(n=77)$ & $(n=43)$ & $(n=42)$ & $(n=78)$ \\
\hline $\begin{array}{c}\text { Benefits of herd } \\
\text { mobility for manure } \\
\text { availability }\end{array}$ & & & & \\
\hline $\begin{array}{c}\text { Increased availability } \\
\text { of manure }\end{array}$ & 18.2 & 16.3 & 0 & 29.5 \\
\hline $\begin{array}{l}\text { Substitution of mineral } \\
\text { fertilizer by organic } \\
\text { fertilizer }\end{array}$ & 35.1 & 44.2 & 0 & 14.1 \\
\hline $\begin{array}{l}\text { Increased land use for } \\
\text { cattle penning }\end{array}$ & 10.4 & 14.0 & 2.4 & 26.9 \\
\hline Nothing & 36.4 & 25.6 & 97.6 & 29.5 \\
\hline $\begin{array}{c}\text { Changes in crop yield } \\
\text { after transhumant } \\
\text { passage }\end{array}$ & & & & \\
\hline Yield increase & 61.0 & 34.9 & 23.8 & 33.3 \\
\hline Yield decrease & 22.1 & 4.7 & 71.4 & 17.9 \\
\hline No change & 16.9 & 60.5 & 4.8 & 48.7 \\
\hline $\begin{array}{c}\text { Changes observed on } \\
\text { soil after transhumant } \\
\text { passage }\end{array}$ & & & & \\
\hline Soil erosion & 49.4 & 16.3 & 0 & 0 \\
\hline Soil less productive & 7.8 & 16.3 & 71.4 & 16.7 \\
\hline Soil more productive & 36.4 & 4.7 & 23.8 & 33.3 \\
\hline Nothing & 6.5 & 62.8 & 4.8 & 50.0 \\
\hline $\begin{array}{l}\text { Changes in feed } \\
\text { resources after } \\
\text { transhumant passage }\end{array}$ & & & & \\
\hline $\begin{array}{c}\text { Disappearance of } \\
\text { valuable grass species }\end{array}$ & 26.0 & 2.3 & 4.8 & 7.7 \\
\hline $\begin{array}{c}\text { Expansion of invasive } \\
\text { species }\end{array}$ & 29.9 & 2.3 & 71.4 & 5.1 \\
\hline $\begin{array}{c}\text { Valuable species of } \\
\text { grasses disappear } \\
\text { while invasive species } \\
\text { proliferate }\end{array}$ & 40.3 & 9.3 & 16.7 & 17.9 \\
\hline Nothing & 3.9 & 86.0 & 7.1 & 69.2 \\
\hline
\end{tabular}

\section{Discussion}

\subsection{Challenges for Pastoral Resource Use and Management}

The presence of agro-pastoral medium-size herders with small areas of cropland and crop farmers with large areas of cultivated land and small herds in Kandi is consistent with the social change previously reported by Djenontin et al. (2004) [52] for this region. This trend towards mixed farming systems and agricultural intensification has been described for many West African pastoral areas as a recent coping strategy, whereby herders settled due to increases in population density and environmental pressures [58-60]. Our results suggest that the big crop farmers owning small herds are autochthonous households who shifted from sole crop farming to an integrated faming system after purchasing cattle. The medium-size herders with small cropland areas are pastoralists who settled and now practice crop farming and cattle herding. Desta and Coppock (2003) [61] observed that agricultural intensification in pastoralism systems is associated with a decline in per capita cattle numbers. This confirms the reduction of cattle herd numbers and the high production of cotton by farmers described by Djenontin et al. (2004) [52] for Kandi. The same notion is corroborated by the small- and medium-size cattle herds and the large areas of cultivated 
land that coexist in the same area. In contrast to Kandi, a relatively high number of pure crop farmers and pure herders with large cattle herds were observed in Kétou. This suggests a poor integration of livestock with crop farming and may be indicative for a recent process of transhumant herders settling in this region, as observed in other pastoral areas of southern Benin [62].

The use of cultivated land for grazing by cattle herders, the practice of permanent grazing and of transhumance, mostly observed in Kandi, suggest a critical unavailability of pasture areas. The reduction of grazing areas can be attributed to the expanding cotton cropping [63]. According to Little and McPeak (2014) [7], the loss of grazing land forces African herders to find new pastoral resources and increases the vulnerability of pastoralism. In Kétou, rangelands are contested by the sedentarization of herders and the yearly passage of many transhumant herds [8]. The presence of well-appreciated Poaceae species as reported by farmers in Kétou may elucidate the attraction of this area to transhumant herders. In contrast, the absence of palatable grasses on the pastures in Kandi supports the perception of farmers that local rangelands are strongly degraded. Furthermore, the appreciation of tree leaves by Kandi's agro-pastoralists is in line with the increasing use of fodder trees by many herders in northern and central Benin [64].

This is a common phenomenon in Benin, especially during the dry months where good-quality forages are scarce [48]. This surely contributes to land degradation and concurred with previous findings [37] in the natural rangelands of the Classified Forest of the Upper Alibori, Benin where the vegetation cover has consistently changed from 2000 to 2015 with significant decreases of woodlands and savanna woodlands.

The regular influx of foreign transhumant herds in the region, in addition to the local herds, explains the degradation of pastures in Kandi, according to most respondents. A recent study [25] on pasture management by transhumant herders in two host areas in Benin identified poor distribution of livestock on the pastures as one of the causes for overgrazing and pasture degradation. This was associated with the spread of invasive species, which infers that land degradation is more pronounced in areas of high than of low transhumance. Nevertheless, the ecological processes leading to rangeland degradation are complex and cannot solely be attributed to cattle herding. In Kandi, farmers reported high rates of mineral fertilization. This practice coincides with the intensive cotton production in the region that often leads to dependencies and negative environmental externalities [27]. Another main cause of land degradation is the practice of bush fires [64] that is mainly observed in Kétou. Farmers' responses on the occurrence of bush fires in this area were confirmed by ground-truthing data in Kétou, where old and recent signs of fires were determined on wooded and shrub savannas and on croplands. While croplands are increasingly degraded by the sole use of mineral fertilization and bush fires, only few agro-pastoralists in Kandi and Kétou practice organic fertilization and fallowing, which both could be beneficial for croplands' recovery. The shortening of fallow periods is consistent with the shortage of land and intensification of crop production. While pointing to the impacts of reduced fallowing and manuring practices on African croplands, other authors [65] have stressed the need to improve agricultural practices by integrated soil fertility management. The main strategy that half of the surveyed farmers often use to manage soil fertility is crop rotation. These results corroborated earlier ones [66] in the same study area. Crop rotation, however, needs to be more promoted and associated with other soil management strategies, such as manuring. That said, classical studies [63] argued that crop rotation alone is insufficient to counterbalance the effects of declining soil fertility and erosion on land productivity. Yet, manuring contracts with pastoralists could greatly contribute to cropland restoration, improve soil fertility, and increase food production, thereby reducing conflicts between pastoralists and farmers.

\subsection{Farmers' and Herders' Perceptions of Rangeland Degradation}

The agro-pastoralists, which included pure and big crop farmers with small herds, who cultivated large areas of land, had only little to no experience in cattle keeping. 
Hence, land degradation and resource scarcity are reflecting cattle herding strategies and overgrazing. In contrast, the majority of herders indicated that bush fires remain a main contributor to rangeland degradation. Indiscriminate bush burning, in addition to destruction of crops, contamination of streams by cattle, and overgrazing of land have been reported previously [67] for the Delta State of Nigeria, as the causes of land degradation and conflicts between farmers and nomadic cattle herders. Likewise, in Kemon and Kokey, two villages of central and northern Benin, respectively, crop damages by cattle in areas where agriculture has become more widespread, and the blocking of cattle routes have been identified as the major causes of conflict between herders and farmers [68].

In the current study, the views of the various agro-pastoralists and the herders observed reflect the conflictual relationship often described between them in rangeland use $[9,43,63]$ and confirm our hypothesis that the perceptions of rangeland degradation by different land users depend on their socio-economic conditions and their use of the rangeland. Furthermore, the contradictory perceptions were more pronounced in Kétou, confirming the poor integration of agriculture with livestock as mentioned above. In accordance with an earlier study [13], the influence of socio-professional groups on respondents' perception of the impact of transhumant practices on the status of natural resources may be explained by the fact that members of different socio-professional groups pursue diverse and competitive interests. Herders seek land to graze their animals, while farmers claim the same lands to produce food or cash crops. Although land is not extendable, it is important to reconcile the two actors for the participative use of this resource to avert conflicts. Although quarrels between crop farmers and cattle herders have been reported by the majority of the respondents, their causes were still perceived differently. In addition to crop destruction by herds noticed by crop farmers and agro-pastoralists, and the occupation of livestock corridors criticized by herders, the killing of cattle or even people as mentioned by herders reveals the extent of damage such situations may cause. Several authors who highlighted the need for a strategic reconciliation of various actors for better management of rangelands have mentioned similar causes for farmer-herder conflicts in agro-pastoral areas $[9,63,69]$. The main source of conflict is the difficulty of pastoralists to move freely with their herds, owing to the blockage of livestock corridors or of areas originally dedicated to livestock grazing and mobility $[9,70]$. The occupation of pastoral infrastructures by crop farmers is often the consequence of the extension of cultivated land. This is consistent with the response of pure or big crop farmers and some agro-pastoralists surveyed in this study who, by simple use, have rights over communal grazing land and often exclude members of other communities from using the same communal land for grazing their cattle. Comparable observations have been previously made in Djougou (northwest Benin) [71], where Fulani cattle herders are usually considered as foreigners by local crop farmers as well as community leaders. In many African countries, this conflicting situation is supported by national laws [70,72]. Other authors [69] have pointed out the strong relation between social identities, property regimes, and conflicts over dryland resources, while studies in Mali [70] and Ghana [73] have described how herder marginalization can determine conflict outbreaks in pastoral systems and their resolution by local authorities. The marginalization of herders' in the use of communal rangelands corroborates with the perception of the majority of crop farmers on transhumance in the present study.

For the majority of crop farmers, herd mobility is a threat for local rangeland resources as it causes land degradation and unproductiveness, as well as the disappearance of valuable fodder grasses. On the contrary, transhumance, according to the herders, is rather beneficial for local rangelands as it allows the valorization of uncropped lands, thereby enhancing their productivity via manure addition. In the same vein, some scientists [18] argue that the perceptions and positions of the different actors involved in the transhumance process reflect their personal interests and socio-cultural setting, which influences their land management practices.

A review of local land management experiences in West Africa reveals that the resolution of conflicts over the uses of resources between herders and farmers depends on 
factors like land and water rights, promotion of the interests of pastoral groups, and the intervention of traditional and modern institutions in conflict resolution [70]. This supposes, of course, political willingness on the part of the government to assist pastoral groups without neglecting their socio-economic and environmental links with other groups [70].

As described previously [74,75], it is obvious that by increasing cattle numbers in pastoral areas, transhumance will intensify competition for and pressure on local land resources, which under specific conditions, can lead to overgrazing and subsequent rangeland degradation. Nevertheless, the role of transhumance in the regeneration of soil fertility through the deposition of manure has also been highlighted in recent studies [2,4]. A recent experiment [27] confirmed the positive effect of livestock integration on soil quality in crop farming systems. Congruent other studies [76], manuring contracts have been reported between transhumant and autochthonous farmers in northern Benin. It has also been argued [2] that herd mobility is part of the regional integration of livestock with cropping systems, while some authors [65] encouraged the intensification of manure production, and its sound management and rational use as a valuable way to cope with malnutrition challenges in semiarid African regions. It is therefore evident that pastoralism, food cropping, and rangeland management should be combined in such a way that one is complementary to the other for the benefit of agro-pastoral ecosystems [6]. A diversified crop-livestock system aimed at reducing cattle offtake, adapted to natural resource competition and insecurity by extensification, with further diversification into off-farm activities to spread risk, increases livelihood security and captures opportunities [61]. Denying the opportunities that livestock mobility can bring about in complex semi-arid environments could be harmful for both pastoral ecosystems and livestock production [18,20]. Some studies [77] observed that farmers' resettlement can be ecologically and economically unsustainable as it reduces their efficiency in resource use. In order to cope with the challenge of food security and sustain the resilience of pastoral livelihoods, it is therefore crucial to strengthen and sustain the benefits of the crucial strategy of herd mobility such as diversity of animals, traditional knowledge, social reciprocity, and flexibility in an unsteady and unpredictable environment $[78,79]$. However, the question remains how best to achieve these goals in the current context of resources competition associated with rangeland degradation and land shrinkage. Moreover, we need to better understand which trade-offs exist between livestock, crops, environment, and society in view of livelihoods and food security [80]. The intensification of crop-livestock farming has to integrate the biomass and nutrient flows between cropping and livestock activities to lead to productive land and sustainable outcomes [81]. This merits further reflection and concerted action of all stakeholders, pastoralists, crop farmers, scientists, and political authorities.

\section{Conclusions}

The present study provides evidence of ongoing transformational changes and the conflictual context of rangeland management and farmers' livelihood strategies in Benin. With the increase of mixed farming systems in many areas of the country, the use of pastoral lands has become more competitive. However, the current management practices employed by the surveyed farmers seem to challenge the sustainability of this resource and might contribute to its degradation. Mobile pastoralism allows the exploitation of unused lands and improves soil fertility by the recycling of carbon and plant nutrients from rangelands to agricultural areas. In effect, many crop farmers are opposing herd mobility and the use of rangeland by cattle herders, seeing the latter as mainly responsible for land degradation. Moreover, many settled crop-livestock farmers now consider rangelands as their personal property. Such socio-economic tensions are supported by herder-unfriendly national policies. It remains to explore whether with the newly voted pastoral code in Benin, and all the expected changes in the regulation of pastoralism, land degradation, and conflicts will reduce. All in all, participative management and strong enforcement of the rules are required, particularly in the country's southern areas as they are more prone to conflicts owing to mismanagement both by farmers and herders and inappropriate resource 
use. Our findings highlight the need to promote participative management practices in pastoral areas together with crop farmers and herders to sustain rural livelihoods and face tomorrow's challenges of food security.

Supplementary Materials: The following are available online at https:/ / www.mdpi.com/article/10 $.3390 /$ land10040425/s1, Figure S1. Distribution of the different sub-groups of farmers surveyed in the municipalities of Kandi in northeastern and Kétou in southeastern Benin; Table S1: Descriptions of the subgroups, Table S2: Herders practices and rangeland use, Table S3: Different practices of agro-pastoralists on lands $(n=119)$.

Author Contributions: Conceptualization, R.V.C.D. and L.H.D.; methodology, R.V.C.D. and L.H.D.; formal analysis, S.F.U.V.; investigation, B.D.A. and K.H.D.; resources, R.V.C.D.; data curation, S.F.U.V., R.V.C.D. and L.H.D.; writing-original draft preparation, R.V.C.D. and S.F.U.V.; writing-review and editing, R.V.C.D., L.H.D., M.H., E.S. and A.B.; supervision, R.V.C.D.; project administration, R.V.C.D.; funding acquisition, R.V.C.D. All authors have read and agreed to the published version of the manuscript.

Funding: This research was funded by VolkswagenStiftung, Hannover, Germany, through grant Az 89368.

Institutional Review Board Statement: Not applicable.

Informed Consent Statement: Informed consent was obtained from all subjects involved in the study.

Data Availability Statement: The data presented in this study are available on request from the corresponding author. The data are not publicly available due to the promise made to farmers and herders to use the data for research purpose only.

Acknowledgments: The authors are grateful to all farmers for their participation in the present study and valuable help in data collection.

Conflicts of Interest: The authors declare that there is no conflict of interest.

\section{References}

1. Ly, C.; Fall, A.; Okike, I. West Africa: The Livestock Sector in Need of Regional Strategies. In Livestock in a Changing Landscape: Experiences and Regional Perspectives; Island Press: Washington, DC, USA; Covelo, CA, USA; London, UK, 2010.

2. Krätli, S.; Huelsebusch, C.; Brooks, S.; Kaufmann, B. Pastoralism: A Critical Asset for Food Security Under Global Climate Change. Anim. Front. 2013, 3, 42-50. [CrossRef]

3. Samuels, M.I. Pastoral Mobility in a Variable and Spatially Constrained South African Environment. PhD Thesis, University of Cape Town, Cape Town, South Africa, 2013.

4. Ayantunde, A.A.; Asse, R.; Said, M.Y.; Fall, A. Transhumant Pastoralism, Sustainable Management of Natural Resources and Endemic Ruminant Livestock in the Sub-Humid Zone of West Africa. Environ. Dev. Sustain. 2014, 16, 1097-1117. [CrossRef]

5. Homewood, K. Ecology of African Pastoralist Societies; James Currey: Oxford, UK; Ohio University Press: Athens, OH, USA; Unisa Press: Pretoria, South Africa, 2008.

6. Abule, E.; Snyman, H.A.; Smit, G.N. Comparisons of Pastoralist's Perceptions about Rangeland Resource Utilisation in the Middle Awash Valley of Ethiopia. J. Environ. Manag. 2005, 75, 21-35. [CrossRef] [PubMed]

7. Little, P.D.; McPeak, J.G. Resilience and Pastoralism in Africa. In 2020 Conference Paper; International Food Policy Research Institute (IFPRI): Addis Ababa, Ethiopia, 2014; Volume 9.

8. ANOPER. La Situation Actuelle de L'élevage et des Éleveurs De Ruminants au Bénin: Analyse et Perspectives. Annexe du Document D'orientation Stratégique de l'ANOPER. 2014. Available online: https:/ /www.inter-reseaux.org/wp-content/ uploads/DOS_ANNEXE_ANOPER-1.pdf (accessed on 4 March 2021).

9. Lesse, P.; Houinato, M.R.; Djenontin, J.; Dossa, H.; Yabi, B.; Toko, I.; Tente, B.; Sinsin, B. Transhumance en République du Bénin: États des Lieux et Contraintes. Int. J. Biol. Chem. Sci. 2015, 9, 2668-2681. [CrossRef]

10. FAO. La Transhumance Transfrontalière en Afrique de l'Ouest, Proposition de Plan D'action. 2012. Available online: http: //www.inter-reseaux.org/IMG/pdf/Transhumance_Transfrontalier_en_AO_Rapport_FAO.pdf. (accessed on 3 January 2021).

11. Bassett, T.J.; Turner, M. Sudden Shift or Migratory Drift? FulBe Herd Movements to the Sudano-Guinean Region of West Africa. Hum. Ecol. 2007, 35, 33-49. [CrossRef]

12. Umutoni, C.; Ayantunde, A.A.; Sawadogo, G.J. Local Knowledge of Transhumance Practices in the Sudano-Sahelian Zone of Mali. Rev. Élevage Méd. Vét. Pays Trop. 2016, 69, 53-61.

13. Umutoni, C.; Ayantunde, A.A. Perceived Effects of Transhumant Practices on Natural Resource Management in Southern Mali. Pastor. Policy Pract. 2018, 8, 8. [CrossRef] 
14. Umutoni, C.; Ayantunde, A.; Turner, M.; Sawadogo, G.J. Community Participation in Decentralized Management of Natural Resources in the Southern Region of Mali. Environ. Nat. Resour. Res. 2016, 6, 1-15. [CrossRef]

15. Achiba, G.A. Managing Livelihood Risks: Income Diversification and the Livelihood Strategies of Households in Pastoral Settlements in Isiolo County, Kenya. Pastor. Policy Pract. 2018, 8, 20. [CrossRef]

16. Al-bukhari, A.; Hallett, S.; Brewer, T. A Review of Potential Methods for Monitoring Rangeland Degradation in Libya. Pastor. 2018, 8, 13. [CrossRef]

17. Williams, T.O. Multiple Uses of Common Pool Resources in Semi-Arid West Africa: A Survey of Existing Practices and Options for Sustainable Resource Management. Nat. Resour. Perspect. 1998, 38, 1-8.

18. Schönegg, G.; Martel, P.; Sano, B.; Noufou, S.; Zeh, M. Les Conflits Liés à la Transhumance Transfrontalière Entre le Niger, le Burkina Faso et le Bénin; DED, Fachreferat für Ländliche Entwicklung, Wasserwirtschaft und Ressourcennutzung: Bonn, Germany, 2006.

19. Baker, L.E.; Hoffman, M.T. Managing Variability: Herding Strategies in Communal Rangelands of Semiarid Namaqualand, South Africa. Hum. Ecol. 2006, 34, 765-784. [CrossRef]

20. Butt, B. Pastoral Resource Access and Utilization: Quantifying the Spatial and Temporal Relationships Between Livestock Mobility, Density and Biomass Availability in Southern Kenya. Land Degrad. Dev. 2010, 21, 520-539. [CrossRef]

21. Smith, R.J. Assessing Overgrazing in Savannas. In Savannas and Dry Forests: Linking People with Nature; Mistry, J., Beradi, A., Eds.; Ashgate Publishing: Burlington, VT, USA, 2006; pp. 105-128.

22. Butt, B.; Turner, M.D.; Singh, A.; Brottem, L. Use of MODIS NDVI to Evaluate Changing Latitudinal Gradients of Rangeland Phenology in Sudano-Sahelian West Africa. Remote Sens. Environ. 2011, 115, 3367-3376. [CrossRef]

23. Green, A.; Tchinlé, J. Evaluation of Mbororo Transhumance Routes in the Tchabal Mbabo-Dodeo Region of Cameroon, Gashaka Gumti-Tchabal Mbabo Transboundary Conservation Project Report; BirdLife International: Cambridge, UK, 2004.

24. Kiema, A.; Tontibomma, G.B.; Zampaligre, N. Transhumance et Gestion des Ressources Naturelles au Sahel: Contraintes et Perspectives Face aux Mutations des Systèmes de Productions Pastorales. VertigO 2014, 14. [CrossRef]

25. Diogo, R.V.C.; Dossa, L.H.; Adjassin, J.S.; Gnavo, P.G.T.; Alkoiret, I.T. Gestion des Pâturages par les Éleveurs Transhumants dans Deux Zones D'accueil au Bénin. In Le Pastoralisme dans le Courant des Changements Globaux: Défis, Enjeux et Perspectives Dakar, Senegal, 20-24 November 2017; Camara, A.D., Taugourdeau, S., Eds.; Book of Abstracts: Dakar, Senegal; pp. 31-32.

26. Pistocchini, E.; Stella, S.; Belli, P.; Cantafora, A.F.A.; Turini, J.; Zecchini, M.; Crimella, C. Dairy Production in Peri-Urban Area of Niamey: Milk Quality and Microbial Contamination. Trop. Anim. Health Prod. 2009, 41, 145-147. [CrossRef] [PubMed]

27. Acosta-Martínez, V.; Zobeck, T.M.; Allen, V. Soil Microbial, Chemical and Physical Properties in Continuous Cotton and Integrated Crop-Livestock Systems. Soil Sci. Soc. Am. J. 2004, 68, 1875-1884. [CrossRef]

28. Steinfeld, H.; Mooney, H.A.; Schneider, F.; Neville, L.E. Livestock in a Changing Landscape, Volume 1: Drivers, Consequences, and Responses; Island Press: Washington, DC, USA; Covelo, CA, USA; London, UK, 2013.

29. Yu, L.; Zhou, L.; Liu, W.; Zhou, H.-K. Using Remote Sensing and GIS Technologies to Estimate Grass Yield and Livestock Carrying Capacity of Alpine Grasslands in Golog Prefecture, China. Pedosphere 2010, 20, 342-351. [CrossRef]

30. Maczko, K.; Tanaka, J.A.; Breckenridge, R.; Hidinger, L.; Heintz, H.T.; Fox, W.E.; Kreuter, U.P.; Duke, C.S.; Mitchell, J.E.; McCollum, D.W. Rangeland Ecosystem Goods and Services: Values and Evaluation of Opportunities for Ranchers and Land Managers. Rangelands 2011, 33, 30-36. [CrossRef]

31. Schuman, G.E.; Janzen, H.H.; Herrick, J.E. Soil Carbon Dynamics and Potential Carbon Sequestration by Rangelands. Environ. Pollut. 2002, 116, 391-396. [CrossRef]

32. Favretto, N.; Stringer, L.; Dougill, A.; Dallimer, M.; Perkins, J.; Reed, M.; Atlhopheng, J.; Mulale, K. Multi-Criteria Decision Analysis to Identify Dryland Ecosystem Service Trade-offs Under Different Rangeland Land Uses. Ecosyst. Serv. 2016, 17, 142-151. [CrossRef]

33. AU-IBAR. Rational Use of Rangelands and Fodder Crop Development in Africa. In AU-IBAR Monographic Series No. 1; African Union Interafrican Bureau for Animal Resources (AU-IBAR): Nairobi, Kenya, 2012.

34. Djenontin, J.A. Dynamique des Stratégies et des Pratiques D'utilisation des Parcours Naturels pour L'alimentation des Troupeaux Bovins au Nord-Est du Bénin. Ph.D. Thesis, Université d'Abomey Calavi, Godomey, Bénin, 2011; p. 274.

35. Idrissou, L.; Aarts, N.; Leeuwis, C.; Van Paassen, A. Identity Dynamics and Conflict in Collaborative Processes: The Case of Participatory Management of Protected Areas in Benin. J. Environ. Prot. 2016, 7, 1981-2008. [CrossRef]

36. Idrissou, L.; Mama Zakari, I.; Egah, J.; Baco, M.N. Dynamics of Conflicts between Crop Farmers and Pastoralists Over AgroPastoral Resources in Northern Benin. Eur. J. Bus. Soc. Sci. 2017, 6, 12-28. Available online: http://www.ejbss.com/recent.aspx-/ (accessed on 15 January 2021).

37. Seidou, A.A.; Agbayigbo, A.A.; Traore, I.A.; Houinato, M. Spatio-Temporal Dynamics of Natural Rangelands Exploited by Transhumance Cattle Herds in the Classified Forest of Upper Alibori, Northern Benin. Am. Sci. Res. J. Eng. Technol. Sci. 2017, 33, 111-123.

38. Tamou, C.; Ripoll-Bosch, R.; de Boer, I.J.; Oosting, S.J. Pastoralists in a Changing Environment: The Competition for Grazing Land in and Around the W Biosphere Reserve, Benin Republic. Ambio 2018, 47, 340-354. [CrossRef] [PubMed]

39. Reid, R.S.; Thornton, P.K.; Kruska, R.L. Loss and Fragmentation of Habitat for Pastoral People and Wildlife in East Africa: Concepts and Issues. Afr. J. Range Forage Sci. 2004, 21, 171-181. [CrossRef]

40. Ayantunde, A.A.; Fernández-Rivera, S.; Hiernaux, P.H.; Tabo, R. Implications of Restricted Access to Grazing by Cattle in Wet Season in the Sahel. J. Arid Environ. 2008, 72, 523-533. [CrossRef] 
41. Diogo, R.V.C.; Schlecht, E.; Buerkert, A.; Rufino, M.C.; van Wijk, M.T. Increasing Nutrient Use Efficiency Through Improved Feeding and Manure Management in Urban and Peri-Urban Livestock Units of a West African city: A Scenario Analysis. Agric. Syst. 2013, 114, 64-72. [CrossRef]

42. Mortimore, M. Adapting to Drought in the Sahel: Lessons for Climate Change. Wiley Interdiscip. Rev. Clim. Chang. 2010, 1, 134-143. [CrossRef]

43. Moritz, M. Understanding Herder-Farmer Conflicts in West Africa: Outline of a Processual Approach. Hum. Organ. 2010, 69, 138-148. [CrossRef]

44. Bassett, T.J.; Crummey, D. African Savannas: Global Narratives and Local Knowledge of Environmental Change; James Currey: Oxford, UK, 2003.

45. Sidi Imorou, H. Eleveurs, Bovins de Race Borgou et Prédiction de la Valeur Nutritive des Ligneux Fourragers les plus Appétés du Nord-Bénin. Ph.D. Thesis, Université d'Abomey, Calavi, Bénin, 2016; p. 236.

46. De Haan, C.; Dubern, E.; Garancher, B.; Quintero, C. Pastoralism Development in the Sahel; World Bank: Washington, DC, USA, 2016; Available online: https:/ / openknowledge.worldbank.org/bitstream/handle/10986/24228/K8813.pdf? sequence=2 (accessed on 14 February 2019).

47. Young, H.; Behnke, R.; Sulieman, H.; Robinson, S.; Mohamed, A. Risk, Resilience, and Pastoral Mobility; Feinstein International Center: Somerville, MA, USA, 2016; Available online: http:/ / fic.tufts.edu/assets/TUFTS_1611_Risk_Resilience_mobility_V6 _online.pdf (accessed on 12 February 2021).

48. Diogo, R.V.C.; Adjassin, J.S.; Dossa, L.H.; Traoré, I.A. Feeding and Spatial Behaviours of Transhumant Cattle in Southern Benin: Implications for the Sustainable Management of Rangelands. Afr. J. Range Forage Sci. 2020, 37, 268-277. [CrossRef]

49. Catley, A.; Lind, J.; Scoones, I. Pastoralism and Development in Africa: Dynamic Change at the Margins; Routledge: London, UK, 2013; 328p, ISBN 9781136255854.

50. Houessou, S.O.; Dossa, L.H.; Diogo, R.V.C.; Houinato, M.; Buerkert, A.; Schlecht, E. Change and Continuity in Traditional Cattle Farming Systems of West African Coast Countries: A Case Study from Benin. Agric. Syst. 2019, 168, 112-122. [CrossRef]

51. Van Driel, A. Sharing a Valley: The Changing Relations Between Agriculturalists and Pastoralists in the Niger Valley of Benin. Ph.D. Thesis, University of Amsterdam, Amsterdam, The Netherlands, 2001; p. 220.

52. Djenontin, J.A.; Amidou, M.; Baco, N.M. Diagnostic Gestion du Troupeau: Gestion des Ressources Pastorales dans les Départements de l'Alibori et du Borgou au Nord Bénin. Bull. Rech. Agron. Bénin 2004, 43, 30-45.

53. Tamou, C. Understanding Relations Between Pastoralism and its Changing Naturel Environment. Ph.D. Thesis, Wageningen University, Wageningen, The Netherlands, 2017; p. 165.

54. Adjovi, A.N.R. Monographie de la Commune de Kandi; Cabinet Afrique Conseil: Cotonou, Benin, 2006.

55. Bani, G. Monographie de la Commune de Kétou; Cabinet Afrique Conseil: Cotonou, Benin, 2006.

56. Dossa, L.H.; Sangaré, M.; Buerkert, A.; Schlecht, E. Intra-Urban and Peri-Urban Differences in Cattle Farming Systems of Burkina Faso. Land Use Policy 2015, 48, 401-411. [CrossRef]

57. IBM Corp. IBM-SPSS 24.0; SPSS Inc.: Chicago, IL, USA, 2016.

58. Okoruwa, V.; Jabbar, M.A.; Akinwumi, J.A. Crop-Livestock Competition in the West African Derived Savanna: Application of a Multi-Objective Programming Model. Agric. Syst. 1996, 52, 439-453. [CrossRef]

59. Powell, J.M.; Pearson, R.N.; Hiernaux, P.H. Crop-Livestock Interactions in the West African Drylands. Agron. J. 2004, 96, 469-483.

60. Majekodunmi, A.O.; Dongkum, C.; Langs, T.; Shaw, A.P.; Welburn, S.C. Shifting Livelihood Strategies in Northern NigeriaExtensified Production and Livelihood Diversification Amongst Fulani Pastoralists. Pastoralism 2017, 7, 19. [CrossRef]

61. Desta, S.; Coppock, D.L. Pastoralism Under Pressure: Tracking System Change in Southern Ethiopia. Hum. Ecol. 2004, 32, 465-486. [CrossRef]

62. Ange, M.; Kinhou, B.; Sinsin, B. Transhumance and Conflicts Management on Agonlin Plateau in Zou Department (Benin). J. Biodivers. Environ. Sci. 2014, 4, 132-145.

63. De Haan, L. Gestion de Terroir at the Frontier: Village Land Management Including Both Peasants and Pastoralists in Benin. In The Arid Frontier. Interactive Management of Environment and Development; Bruins, H.J., Lithwick, H., Eds.; Kluwer Academic Publishers: Boston, MA, USA, 1998; pp. 209-277.

64. Sèwadé, C.; Azihou, A.F.; Fandohan, A.B.; Houéhanou, T.D.; Houinato, M. Diversité, Priorité Pastorale et de Conservation des Ligneux Fourragers des Terres de Parcours en Zone Soudano-Guinéenne du Bénin. Base 2016, 20, 1-13.

65. Ganry, F.; Feller, C.; Harmand, J.M.; Guibert, H. Management of Soil Organic Matter in Semiarid Africa for Annual Cropping systems. Nutr. Cycl. Agroecosyst. 2001, 61, 105-118. [CrossRef]

66. Djenontin, J.A.; Wennink, B.; Dagbenongbakin, G.; Ouinkoun, G. Pratiques de Gestion de Fertilité dans les Exploitations Agricoles du Nord-Bénin. In Savanes Africaines: Des espaces en Mutation, des Acteurs Face à de Nouveaux Défis; Actes du Colloque; Cirad-Prasac: Garoua, Cameroon, 2003.

67. Ofuoku, A.U.; Isife, B.I. Causes, Effects and Resolution of Farmers-Nomadic Cattle Herder's Conflict in Delta State, Nigeria. Agric. Trop. Subtrop. 2010, 43, 33-41.

68. Djedjebi, T.; de Hann, L.J. Local Land Management in Benin With Special Reference to Pastoral Groups. In Farmers and Scientists in a Changing Environment: Assessing Research in West Africa; Renard, G., Krieg, S., Lawrence, P., von Oppen, M., Eds.; Margraf Verlag: Weikersheim, Germany, 2000; ISBN 3-8236-1318-9. 
69. Le Meur, P.Y.; Hochet, P. Property Relations by Other Means: Conflict over Dryland Resources in Benin and Mali. Eur. J. Dev. Res. 2010, 22, 643-659. [CrossRef]

70. Benjaminsen, T.A.; Ba, B. Farmer-Herder Conflicts, Pastoral Marginalisation and Corruption: A Case Study from the Inland Niger delta of Mali. Geogr. J. 2009, 175, 71-81. [CrossRef]

71. Ciavolella, R. Les Dilemmes du Pastoralisme. Entre Marginalisation et Modernisation Chez les Éleveurs Peuls à Djougou (Bénin); Report ANR; ECLIS: Lisboa, Portugal, 2013.

72. Djenontin, A.J.P.; Houinato, M.; Toutain, B.; Sinsin, B. Pratiques et Stratégies des Éleveurs face à la Réduction de L'offre Fourragère au Nord-Est du Bénin. Science et Changements Planétaires. Sécheresse 2009, 20, 346-353.

73. Tonah, S. Fulani Pastoralists, Indigenous Farmers and the Contest for Land in Northern Ghana. Afr. Spectr. 2002, $37,43-59$.

74. Rowntree, K.; Duma, M.; Kakembo, V.; Thornes, J. Debunking the Myth of Overgrazing and Soil Erosion. Land Degrad. Dev. 2004, 15, 203-214. [CrossRef]

75. Gruber, I. The Impact of Socio-Economic Development and Climate Change on Livestock Management in Benin. Ph.D. Thesis, University of Bonn, Bonn, Germany, 2008.

76. Djohy, G.; Edja, A.H.; Akponikpè, P.I.; Olokesusi, F.; Mahamadou, B. Thwarting Social Conflicts Regarding Water Resources Access in Climate Change Context: Cattle Pastoralists' Schemes in Northern Benin. J. Livest. Sci. 2013, 4, 51-59.

77. Fan, M.; Li, Y.; Li, W. Solving One Problem by Creating a Bigger One: The Consequences of Ecological Resettlement for Grassland Restoration and Poverty Alleviation in Northwestern China. Land Use Policy 2015, 42, 124-130. [CrossRef]

78. Krätli, S. Cattle Breeding, Complexity and Mobility in a Structurally Unpredictable Environment: The WoDaaBe Herders of Niger. Nomadic Peoples 2008, 12, 11-41. [CrossRef]

79. Brockhaus, M.; Djoudi, H.; Locatelli, B. Envisioning the Future and Learning from The Past: Adapting to a Changing Environment in Northern Mali. Environ. Sci. Policy 2013, 25, 94-106. [CrossRef]

80. Herrero, M.; Thornton, P.K.; Gerber, P.; Reid, R.S. Livestock, Livelihoods and the Environment: Understanding the Trade-Offs. Curr. Opin. Environ. Sustain. 2009, 1, 111-120. [CrossRef]

81. Rufino, M.; Gachene, C.K.K.; Diogo, R.V.C.; Hawkins, J.; Onyango, A.A.; Sanogo, O.M.; Wanyama, I.; Yesuf, G.; Pelster, D.E. Sustainable Development of Crop-Livestock Farms in Africa. Front. Agric. Sci. Eng. 2020, 8, 175-181. [CrossRef] 